\title{
Implementation of Centralized Administration and Management of Funds in Enterprise Groups
}

\author{
Xinjian Song* \\ Aluminum Corporation of China, Beijing 100082, China \\ *Corresponding author: Xinjian Song, sxj8731@126.com
}

\begin{abstract}
Enterprise groups are characterized by multiple levels of enterprises with large scales of assets and complex business models. In the process of administration and management of funds, there are often some problems, such as unreasonable internal funds allocation, high financing costs, and flawed funds control. Centralized fund management is a tool for the overall allocation of intra-group funds and the coordinated management of group investment and financing. It can optimize the resource allocation of enterprise groups and reduce financing costs as well as capital risks. By selecting centralized fund management, establishing control and early warning system, as well as building information system and other steps, enterprise groups can better implement centralized fund management and improve their capital control.
\end{abstract}

Keywords: Centralized fund administration and management; Funds control; Financing cost

Publication date: August 2021; Online publication: August 30, 2021

\section{Significance of centralized fund management}

Centralized administration and management of funds is an effective administration and management tool to strengthen groups' resource allocation and improve funds control. For enterprise groups that do not implement centralized fund management, there are often problems, such as unreasonable funds allocation, high financing costs, as well as faced with capital risks. The implementation of centralized administration and management of funds is of great significance in enterprise groups.

\subsection{Optimize resource allocation and reduce financing costs}

In the absence of centralized fund management, the subsidiaries of a group would open separate bank accounts according to their own conditions. The variety and quantity of the accounts lead to the dispersion of the group's funds. Some enterprises have ample funds to idle, resulting in a waste of resources. However, there are other enterprises that lack working capital in the short-term due to insufficient funds or project construction where they need to obtain loans to generate unnecessary expenditure. The funds allocation of enterprises is unreasonable, and their financing costs are high.

Through centralized fund management, the group, from the perspective of an overall strategy, manages the receipt and payment of funds as a whole so that funds can be allocated and adjusted within the group, which does not only guarantee the fundraising of key projects, but also provides financial support to enterprises that are temporarily lacking liquidity so as to reduce the group's redundant funds, avoid the issues of high savings and loans, as well as reduce the financing costs. In addition, the concentration of capital can improve the group's bargaining power over financial institutions and reduce the costs of new financing for enterprises. 


\subsection{Strengthen funds control and prevent capital risks}

Capital is one of the most liquid assets owned by an enterprise. The lack of strong control over it will make various capital management systems become a mere formality. Once there are management loopholes or if the supervision is not in place, capital risks are highly likely to occur. For example, sub-enterprises that are not able to repay their loans in due time would result in credit risks. The execution of funds allocation system and process is not in place, forming "a hall with one person alone having the say," resulting in the loss of the group's capital. The imperfect internal control system of subsidiary enterprises produces loopholes, and the illegal appropriation of funds forms a "private coffer."

Centralized administration and management of funds should be implemented where the main fund revenue and expenditure items of each sub-enterprise would be subjected to centralized approval to prevent various risks. By improving the fund management system, controlling bank accounts, rationally allocating capital resources, as well as examining the income and expenditure of enterprises, the group strengthens their control of the capital of its subsidiaries by examining and approving issues, such as the income and expenditure of funds above the authority and external guarantees so as to prevent and resolve various capital risks, as well as avoid major capital management problems, such as loan maturity, non-payment, illegal guarantee, and misappropriation of funds.

\subsection{Timely grasp information and make accurate decisions}

In the case of dispersed funds, the overall capital situation of the group mainly depends on the enterprises to submit and summarize information regularly according to a certain frequency. This is not convenient for the group to timely grasp information regarding existing funds. The submitted data information lags behind and the degree of accuracy is low. Once the group makes a decision based on the data, there is a decision risk. The centralized management of funds can collect funds regularly, and the group can timely understand the use and balance of funds among their subsidiaries. Combined with the application of information system, accurate information can be obtained so that the group and their subsidiaries can make accurate decisions based on timely information.

\section{Principle of centralized administration and management of funds}

\subsection{Comprehensiveness}

Centralized management of funds should follow the principle of comprehensiveness. When implementing centralized management, all businesses of all subsidiaries involved in the fund management process should be included in the centralized control system. The advantage of doing this is to achieve a full range of management without blind spots or dead corners to strictly prevent capital risks. The inclusion of all businesses means that centralized fund management attaches special importance to the participation of all employees. Leaders, managers, business personnel of the group, business division, and subsidiaries should improve their understanding, unify their thinking, and participate in the construction process of centralized funds control. On the basis of considering the principle of comprehensiveness, the implementation process should also take into account the management needs of the subsidiaries, giving the subsidiaries some discretion to avoid the loss of their enthusiasm, at the same time, reserve some implementation paths to realize the individual management needs of each subsidiary in the funds control system.

\subsection{Security}

Capital is the "blood" of an enterprise. The improvement of group value is reflected in the use and creation of cash cycle. The security of capital is extremely important. First, in the implementation of centralized management, funds are allocated by the group, usually supplementing the cash from cash-rich enterprises 
to cash-strapped subsidiaries. If a cash-strapped subsidiary has a large operating risk due to its business problems, the risk will be transformed into capital risk and transmitted within the group. Second, the centralized management of funds is more stringent for overall risk prevention and control measures of the group. When implementing centralized administration and management of funds, there is a need to comprehensively consider the risk situation of each enterprise, formulate control principles and corresponding schemes, strictly control capital risks, and ensure the safety of the group's overall funds. In general, funding shortfalls due to insufficient short-term operating returns, good subsidiaries but lacking external financing channels, as well as projects that are in line with the company's strategic priorities can be considered for overall funding support.

\subsection{Profitability}

On the premise of ensuring safety, the group should reasonably allocate the capital flow, balance the use, eliminate redundancy, minimize the waste of funds, and improve the profitability of funds. The improvement of profitability is embodied in three aspects: first, through the allocation of internal resources, the scale of external borrowing is reduced, hence the interest expense generated by borrowing is reduced; second, give full play to the advantages of capital concentration, improve the group's credit rating and bargaining power, as well as reduce the financing costs of new financing; third is to build an investment control platform where for unused stock capital, investment varieties with good liquidity can be bought when permitted by regulatory policies to improve capital returns.

\section{Implementation of centralized administration and management of funds}

\subsection{Unified thinking within the group}

Before the implementation of centralized fund management, it is necessary to unify the understanding of the leadership of the parent company and subsidiaries at all levels, strengthen the concept of fund management of the staffs, inculcate the awareness of centralized fund management, and strive for the support of all enterprises. Various ways can be adopted to promote the orderly development of the work. First, a special seminar can be held where the leaders of the group company and its subsidiaries would attend the seminar. The function and significance of centralized fund management should be discussed in the meeting to promote the theory and method of centralized fund management while listening to the opinions of all parties as well as unifying their thinking and understanding. At other important meetings of the company, there is also a need to continuously strengthen the research results. Second, in the preliminary investigation, fully communicate with the administration and management level of each subsidiary and relevant personnel, deeply understand the problems existing in the enterprises' fund administration and management, formulate improvement measures and promotion plans, as well as implement them in the centralized fund management and control plan. Third, during the implementation, field investigation should be carried out on the promotion of the subsidiary companies with timely follow-up of their progress. Then, the promotion plan can be revised, and various problems encountered in the promotion process should be properly solved to ensure the smooth implementation of the plan. Fourth, strengthen the training of relevant personnel. The training should be carried out at different levels and batches. In terms of leadership, it mainly focuses on the concept of centralized fund management training as well as the establishment of system and mechanism, while for middle-level cadres and employees, it mainly focuses on the implementation and application tools of centralized fund management training. Through training, the comprehensive quality of relevant personnel can be enhanced along with their ability improvement in identifying and preventing risks. 


\subsection{Choosing the centralized fund management mode}

Centralized fund administration and management can be divided into four modes: reimbursement center, settlement center, finance company, and capital pool.

The reimbursement center mode is highly centralized where the subsidiary enterprises have very little independent authority. All fund payments exceeding a certain limit need to be approved by the group. Under this management mode, the workload of the fund management department of the group is large, and the implementation of this management mode tends to reduce the enthusiasm of sub-enterprises, which is applicable to small enterprise groups.

Under the mode of settlement center, subsidiaries would open two kinds of accounts: one for income and another for expenditure. The group settlement center implements "two lines of income and expenditure" management for receipts, payments, and settlements of subsidiary enterprises based on the income and expenditure accounts. The advantage of this mode is that the subsidiaries have certain autonomy but the disadvantage is that the settlement center is not an independent legal person and does not have a financial license so it can only carry out business within the group.

A finance company has the status of a legal person where its establishment must be approved by the financial regulatory department. It is a non-bank financial institution. The group can manage the daily fund settlements of its subsidiaries through the financial company, coordinate the allocation of funds, and provide services, such as loan issuance, financing, investment, and financial consultation for its subsidiaries. The characteristics of financial companies as non-bank financial institutions enable them to carry out corresponding businesses outside the group, concentrate the idle funds of the group, and take part in overseas investments to obtain higher returns. As financial companies are subjected to the supervision of the People's Bank of China and other regulatory agencies, they would objectively increase the operating cost of the group. The financial company mode is applicable to enterprise groups with more responsibility centers.

Under the capital pool mode, the group cooperates with commercial banks with strong capital strength. In this case, the group and its subsidiaries at all levels open accounts in cooperative banks which accept the group's entrustments and implement zero-balance management in the accounts of the subsidiaries. If a subsidiary overdraft in the capital pool, it indicates that it is in the state of loan and needs to pay interest. If there are deposits in the capital pool, the subsidiary is in the loan state and can receive corresponding interest. The implementation of capital pool control requires a careful study of laws, tax policies, and other regulations. Under this mode, business contacts between enterprises and cooperative banks are more indepth along with certain risks.

A group needs to comprehensively analyze the development stage, scale, business situation, historical evolution, and other factors of the enterprises in order to select and implement an appropriate mode according to its own characteristics and actual needs.

\subsection{Establishing a control and early warning system}

The implementation of centralized fund management reflects the change of a group's control direction and involves the redistribution of interests of all parties. It is necessary to reform the system and mechanism, as well as improve the supporting management system. After selecting a centralized fund management mode, according to the requirements of the control mode, the organizational structure should be set and personnel allocation should be optimized to ensure that the centralized fund management can be promoted as planned.

Before the implementation, it is necessary to further formulate and implement various capital control systems. First of all, the unified management of bank accounts should be strengthened. On the basis of ensuring normal receipt and payment of funds, enterprises should comprehensively comb the bank accounts, 
distinguish idle accounts and accounts with overlapping functions, as well as close the accounts according to the regulations. For new bank accounts, strict examination and approval procedures should be implemented to ensure that they meet the management requirements. Second, improve the fund budget administration and management system. The fund budget should be prepared according to the actual situation of an enterprise with strict implementation of the fund arrangement and the improvement of the accuracy and guidance of the fund budget. Third, formulate the fund payment examination and approval system, strictly control the process of credit business, as well as formulate the institutional norm of system management. Fourth, improve the internal control management system to ensure the separation of incompatible posts control.

There is a need to establish an early warning and supervisory risk assessment system. One should make full use of the advantages of the information system data integration, establish the early fund risk warning system, monitor the flow of large amounts of capital, set up the fund risk early warning index, and when the monitoring index exceeds the early risk warning index, timely inform the manager of the fund risk. Regularly assessing the key indicators, such as fund concentration and fund budget implementation, can ensure the realization of control objectives. The interior audit department should also strengthen inspection and audit, regularly inspect the group's fund administration and management process, timely report problems found, and give full play to the supervision role of audit inspection.

\subsection{Establishing a centralized fund management information system}

There is a need to build a fund management and control platform in implementing centralized administration and management of funds. Through the construction of the information system, the group can embed various management and control requirements into the management and control process of the information system to ensure the implementation of the group's management and control objectives. The construction of the information system can ensure the authenticity and accuracy of the fund information of subsidiaries at all levels. The group can timely obtain the fund management data and information of the group as a whole and its subsidiaries for real-time processing and analysis to provide basis for decisionmaking and improve the efficiency of capital use.

When building the capital control platform, the integration and docking with other information systems of the group should also be considered. On the one hand, the connection with the budget system can realize the organic combination of the group budget management and fund management, which is conducive to the compilation and analysis of the fund budget. On the other hand, it connects with financial shared service centers to unify the accounting methods involved in the centralized management of funds and play the role of the shared center as a platform to realize the standardization and automation of a series of processes, such as item initiating, budget examination and approval, process control, directly connected payments between banks and enterprises, as well as bookkeeping.

\subsection{Other matters}

First, it is necessary to study the influence of different centralized fund management modes on enterprise tax so as to avoid tax risks while striving for tax incentives. For example, under the current policy, if an enterprise group entrusts a loan to a subordinate unit, as long as the interest charged is not higher than the interest paid when the group receives loan from the outside, it can be exempted from value-added tax (VAT). Second, it is necessary to pay attention to the legal risks in the implementation process. If an enterprise group has both non-listed subsidiaries and a listing platform, it is necessary to focus on the relevant laws and regulations during the implementation of centralized fund management to ensure that the fund collection meets the requirements of various laws and regulations. For subsidiaries with diversified 
ownership structure, the group needs to seek the consent of minority shareholders in advance to collect their funds. Third, cross-border fund collection often involves more restrictive factors. Before collection, relevant domestic and foreign policies should be studied to examine the compliance and feasibility of collection. Overseas fund collection often involves cumbersome operation processes, hence in actual operations, planning of the path should be done in advance along with a response plan.

\section{Conclusion}

As a comprehensive fund management tool, centralized fund management is of practical significance for enterprise groups to optimize resource allocation, prevent capital risks, and reduce financing costs. Under the new situation and background, the competition between enterprises is intensifying, information technology innovation is iterating, management ideas are emerging in endless streams, and financial products are emerging continuously, which objectively also put forward new requirements for groups' capital management. According to the actual situation, enterprise groups should sum up their experiences in practice, weigh the benefits and risks, as well as build a centralized fund management system in line with their own reality.

\section{Disclosure statement}

The author declares that there is no conflict of interest.

\section{References}

[1] Yan L, 2019, Research on the Application and Effect of Centralized Fund Management Theory of Enterprise Groups. Research of Finance and Accounting, (10): 122-4.

[2] Sun K, 2109, Research on Centralized Management of Enterprise Funds under Financial Shared Service Mode, Nanjing Normal University, Nanjing.

[3] Zhang B, 2020, On the Ways and Risks of Centralized Management of "Capital Pools" in Group Finance Companies. Accounting Learning, (11).

[4] Lei Y, 2020, Analysis on Centralized Fund Management of Group Companies. Money China (Academic Edition), (1): 21-2.

[5] Ran H, 2010, Control and Discussion on Centralized Capital Management of Enterprise Groups. Accounting Research, (11): 45-6.

[6] Zhou J, Huang S, Zhang J, 2020, Financial Company or Settlement Center: A Perspective of Centralized Capital Management model in Enterprise Groups. Shanghai Finance, (2): 64-70. 